\section{French Institute of International Relations (IFRI)}

Founded 1979. The Institut Français des Relations Internationales is an independent research and debate institution dedicated to international affairs. Research centres on geographic regions as well as economy; energy; Franco-German relations; health/ environment; migration; identities and citizenship; security and defence; space; and sport.

Address: 27 rue de la Procession, 75740 Paris Cedex 15, France. Website: http://www.ifri.org

Secretary-General: Valérie Genin.

\section{Friedrich Ebert Foundation (Friedrich-Ebert-Stiftung; FES)}

Founded in 1925 as a political legacy of Germany's first democratically elected president, Friedrich Ebert. Non-profit foundation committed to the advancement of public policy issues in the spirit of the basic values of social democracy. Focuses on democracy promotion and international dialogue on the central topics of international politics, globalization, and economic, social and political development in the world.

Address: Berliner Haus, Hiroshimastrasse 17, 10785 Berlin, Germany; Bonner Haus, Godesberger Allee 149, 53175 Bonn, Germany.

Website: http://www.fes.de

President: Kurt Beck.

\section{Fundação Getulio Vargas}

Founded 1944. Higher education establishment dedicated to social sciences research to develop the socio-economic position of Brazil. Research covers business, citizenship, education, finance, justice, health, history, law, macro and microeconomics, politics, pollution, poverty and unemployment, sustainable development and welfare.

Address: Praia de Botafogo 190, Rio de Janeiro, 22250-900

Brazil.

Website: http://www.fgv.br

President: Carlos Ivan Simonsen Leal.

\section{German Council on Foreign Relations}

Founded 1945. Independent, non-partisan and non-profit membership organization and think tank that promotes public debate on foreign policy. Research programmes focus on: China; energy policy; European integration; global economics; international security policy; Middle East; Russia/Eurasia; transatlantic relations.

Address: Rauchstrasse 17-18, D-10787 Berlin, Germany.

Website: https://dgap.org

President: Arend Oetker.

\section{German Institute for International and Security Affairs (Stiftung Wissenschaft und Politik; SWP)}

Founded 1962. Independent scientific establishment that conducts practically oriented research on the basis of which it then advises the Bundestag and the German federal government on foreign and security policy issues. Research divisions: EU integration; EU external relations; international security; the Americas; Russian Federation/CIS; Middle East and Africa; Asia; global issues.
Address: Ludwigkirchplatz 3-4, 10719 Berlin, Germany. Website: http://www.swp-berlin.org

Director: Prof. Dr Volker Perthes.

\section{Heritage Foundation}

Founded 1973. Conservative think tank aiming to formulate and promote public policies based on the principles of free enterprise, limited government, individual freedom, traditional American values and a strong national defence. Target audience includes members of Congress, key congressional staff members, policymakers in the executive branch, the news media, and the academic and public policy communities.

Address: 214 Massachusetts Ave., NE, Washington, D.C., 20002-4999, USA.

Website: http://www.heritage.org

President: Jim DeMint.

\section{Human Rights Watch}

Founded 1978. Non-profit, non-governmental organization dedicated to protecting the human rights of people around the world. Research topics include: arms; children's rights; counterterrorism; disability rights; health; international justice; migrants; press freedom; refugees; terrorism; torture; women's rights.

Address: 350 Fifth Avenue, 34th floor, New York,

NY 10118-3299, USA.

Website: http://www.hrw.org

Executive Director: Kenneth Roth.

\section{Institute for Government}

Founded 2008. Independent charity that works with all the main political parties at Westminster and with senior civil servants in Whitehall to increase government effectiveness. Undertakes research, provides development opportunities for senior decision makers and organizes events for leading international experts to share new thinking on best government. Areas of work: a more effective Whitehall; better policy making; new models of governance and public services; parliament and the political process; leadership for government.

Address: 2 Carlton Gdns, London SW1Y 5AA, UK.

Website: http://www.instituteforgovernment.org.uk

Director: Rt Hon Peter Riddell CBE.

\section{Institute of World Economy and International Relations}

Founded 1956. Non-profit organization that carries out applied socio-economic, political and strategic research. Research areas include: current global problems; economic theory; economic, social and political problems of the transition period in Russia; forecasting and analysis of world economy dynamics and sociopolitical developments; international politics; military and strategic problems; theory of international relations; theory of social and political processes.

Address: 23 Profsoyuznaya St., Moscow 117997, Russia.

Website: http://www.imemo.ru

Director: Alexander A. Dynkin. 